\title{
Plasmid profile, serogrouping, and auxotyping of Neisseria gonorrhoeae isolates from Africa
}

\author{
T O ODUGBEMI, S T BROWN, J BIDDLE, S JOHNSON, G PERKINS, W DEWITT, AND \\ W L ALBRITTON
}

From the Center for Disease Control, Atlanta, Georgia, USA

SUMMARY The plasmid patterns of 90 isolates of Neisseria gonorrhoeae (including 39 penicillinase-producing strains) originating from various countries in Africa were determined. Serogrouping by coagglutination and auxotyping were used to characterise the isolates. The 4-4-megadalton plasmid was present in seven isolates out of 39 penicillinase-producing strains, two of which occurred with a conjugative 24.5-megadalton plasmid. The African strains were predominantly serogroup WI and wild type. Arginine-dependent isolates were as common as proline-dependent types.

\section{Introduction}

New plasmid patterns of Neisseria gonorrhoeae are occurring, and the geography of previously reported plasmid patterns is changing. ${ }^{1-4}$ Jephcott et al ${ }^{1}$ found an endemic focus of penicillinase-producing Neisseria gonorrhoeae (PPNG) with 4.4-megadalton (mdal) plasmid in Britain. The combination of $3.2 \mathrm{mdal}$ plasmid and a $24.5 \mathrm{mdal}$ conjugative plasmid has recently been detected in PPNG isolates from Canada, ${ }^{2}$ the Netherlands, ${ }^{3}$ and Britain. ${ }^{4}$ The recent report ${ }^{5}$ of the detection of $4.4 \mathrm{mdal}$ plasmid in PPNG isolates from Nigeria raises a fundamental question of whether such isolates with $4.4 \mathrm{mdal}$ plasmid were imported into West Africa or were in fact indigenous strains which were unidentified in the other previous studies, ${ }^{67}$ probably because of the limited number of PPNG isolates from Africa. Auxotyping technique ${ }^{89}$ and the new serogrouping method ${ }^{10-13}$ based on antigens designated " $W$ " offer potentially valuable tools for further evaluation of the epidemiology of gonococcal infections from various geographical areas.

In the present study we examined the plasmid content of $N$ gonorrhoeae isolates sent to our laboratory from various countries in Africa. In addition, the serogroup and auxotype of each of the gonococcal isolates were determined.

Address for reprints: Dr T Odugbemi, STD Research Laboratory, Department of Health \& Human Services, Center for Disease Control, Atlanta, Georgia 30333, USA

Accepted for publication 18 August 1982

\section{Material and methods}

Ninety isolates of $N$ gonorrhoeae, including 39 strains of PPNG isolated from patients in various African countries, were studied. The identity of all the gonococcal isolates was reconfirmed in our laboratory at the Center for Disease Control. The $\beta$-lactamase production of each isolate was retested by the chromogenic cephalosporin ${ }^{14}$ and starch paper technique. ${ }^{15}$

Plasmid deoxyribonucleic acid from the cleared lysate of each gonococcal isolate was precipitated with ethanol and subjected to agarose gel electrophoresis. ${ }^{16}$ Plasmids of known molecular weight were included as standards. Nutritional growth requirements of each gonococcal isolate were determined by auxotyping techniques. $^{89}$

Each gonococcal isolate was serogrouped using the coagglutination methods. ${ }^{11-13}$ Reagents were kindly provided by Dr Joan S Knapp (University of Washington, Seattle, USA). The reagent consisted of staphylococci sensitised with hyperimmune rabbit antisera to $N$ gonorrhoeae. A drop of the boiled suspension of the gonococcal cells was mixed with a drop of the reagent. A positive coagglutination reaction was evident after the mixture had been rotated for two minutes. The association of $N$ gonorrhoeae isolates with serogroup and geographical source was assessed by the Loglinear model, $\chi^{2}$ analysis.

\section{Results}

The 90 isolates tested included all the 39 African PPNG strains available in our laboratory from 1977 to 
April 1982. These included isolates from the Central African Republic (6 PPNG/16 non-PPNG), Cameroon (0/3), Ethiopia (0/6), Ghana (7/7), Ivory Coast $(1 / 0)$, Kenya $(5 / 11)$, Nigeria $(16 / 6)$, South Africa (0/2), Zambia (2/0), and Zaire (2/0).

The 4.4 mdal plasmid was found in seven of 39 PPNG isolates examined; two of these also carried a conjugative 24.5 mdal plasmid (table I). The remaining 32 PPNG strains contained the $3 \cdot 2$ mdal plasmid, but none carried the $24 \cdot 5$ mdal plasmid. The cryptic plasmid (2.6 mdal) was present in all PPNG isolates and in 49 of the 51 non-PPNG isolates. Two of the non-PPNG isolates contained the conjugative plasmid. The wild type was predominant in both PPNG and non-PPNG isolates (table II). Only 10 of the 90 strains tested were arginine dependent.

Thirty-four of 39 PPNG isolates were serogroup WI. The African isolates of PPNG were significantly associated with serogroup WI $\left(\chi^{2}=19 \cdot 23, \mathrm{p}=0 \cdot 0001\right)$ (table III). Only 20 of the 51 non-PPNG strains were serogroup WII. All the four PPNG strains from West Africa harbouring the $4.4 \mathrm{mdal}$ plasmid belonged to serogroup WI, while all the three strains from other African countries harbouring $4.4 \mathrm{mdal}$ plasmid belonged to serogroup WII. Only two strains out of 32 PPNG isolates having $3 \cdot 2 \mathrm{mdal}$ plasmid belonged to serogroup WII (table IV).

TABLE I Distribution of plasmids in PPNG from African sources

\begin{tabular}{llll}
\hline & $\begin{array}{l}\text { No of } \\
\text { strains }\end{array}$ & $\begin{array}{l}\text { No of isolates having } \\
\text { plasmids of molecular } \\
\text { weight (megadaltons)* }\end{array}$ \\
\cline { 2 - 4 } Geographical source & tested & $3 \cdot 2$ & $4 \cdot 4$ \\
\hline Central African Republic & 6 & 6 & - \\
Ghana & 7 & 5 & 2 \\
Ivory Coast & 1 & 1 & - \\
Kenya & 5 & 2 & $3+$ \\
Nigeria & 16 & 14 & - \\
Zambia & 2 & 2 & - \\
Zaire & 2 & 2 & 7 \\
Total & 39 & 32 & \\
\hline
\end{tabular}

*All isolates contained a $2.6 \mathrm{mdal}$ plasmid.

tTwo isolates also contained a $24 \cdot 5 \mathrm{mdal}$ plasmid.

PPNG = penicillinase-producing $N$ gonorrhoeae
TABLE III Serogrouping of African isolates of $N$ gonorrhoeae by source of recovery and presence or absence of $\beta$-lactamase production

\begin{tabular}{llll}
\hline \multicolumn{4}{c}{ No (\%) of isolates: } \\
\cline { 2 - 4 } & $\begin{array}{l}\text { Serogroup } \\
W I\end{array}$ & $\begin{array}{c}\text { Serogroup } \\
\text { WII }\end{array}$ & Probability \\
\hline Source of recovery: & $30(77)$ & $7(23)$ & 0.035 \\
$\begin{array}{l}\text { West Africa } \\
\text { Other African countries }\end{array}$ & $24(45)$ & $29(55)$ & \\
$\begin{array}{l}\text { Strain type: } \\
\text { PPNG }\end{array}$ & $34(87)$ & $5(13)$ & $<0.0001$ \\
Non-PPNG & $20(39)$ & $31(61)$ & \\
\hline
\end{tabular}

PPNG = penicillinase-producing $N$ gonorrhoeae

TABLE IV Relationship between auxotype and serogroup of PPNG by plasmid type from African sources

\begin{tabular}{|c|c|c|c|}
\hline \multirow[b]{2}{*}{ Auxotype } & \multicolumn{3}{|c|}{$\begin{array}{l}\text { No of isolates with } 3 \cdot 2 \text { mdal plasmid } \\
\text { (No with } 4 \cdot 4 \text { mdal plasmid) }\end{array}$} \\
\hline & $\begin{array}{l}\text { Serogroup } \\
W I\end{array}$ & $\begin{array}{l}\text { Serogroup } \\
\text { WII }\end{array}$ & Total \\
\hline $\begin{array}{l}\text { Wild type } \\
\text { Pro- } \\
\text { Arg- } \\
\text { Total }\end{array}$ & $\begin{array}{l}20 \\
4^{*}(4) \\
6 \\
30(4)\end{array}$ & $\begin{array}{l}0(1) \\
1(2) \\
1 \\
2(3)\end{array}$ & $\begin{array}{c}20(1) \\
5(6) \\
7\end{array}$ \\
\hline
\end{tabular}

*One isolate required both proline and arginine PPNG = penicillinase-producing $N$ gonorrhoeae

\section{Discussion}

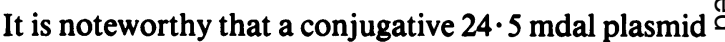
was found in both PPNG and non-PPNG isolates $\overrightarrow{\overrightarrow{0}}$ from African sources in this study. The only two 3 PPNG strains harbouring the conjugative plasmid carried the 4.4 mdal penicillinase plasmid; one of the strains was proline requiring while the other was a wild $\sigma$ type, but both belonged to serogroup WII. Bygdeman et al ${ }^{10}$ reported that all the six PPNG strains from African sources belonged to serogroup WI, even though two of the six strains were arginine requiring; three were wild type and one was proline requiring. Although only six African PPNG strains were reported on by Bygdeman et al, ${ }^{10}$ the results accord

TABLE II Auxotypes of PPNG and non-PPNG from African sources

\begin{tabular}{|c|c|c|c|c|c|c|c|}
\hline \multirow[b]{2}{*}{ Source } & \multirow[b]{2}{*}{ Strain } & \multirow{2}{*}{$\begin{array}{l}\text { No of } \\
\text { isolates } \\
\text { tested }\end{array}$} & \multicolumn{5}{|c|}{ No of isolates with requirements for: } \\
\hline & & & $\begin{array}{l}W i \\
\text { lnc }\end{array}$ & Pro & Arg & $\begin{array}{l}\text { Pro } \\
\text { Arg }\end{array}$ & Isoleucine \\
\hline West Africa * & $\begin{array}{l}\text { PPNG } \\
\text { Non-PPNG }\end{array}$ & $\begin{array}{l}24 \\
13\end{array}$ & $\begin{array}{r}11 \\
4\end{array}$ & $\begin{array}{l}6 \\
7\end{array}$ & $\begin{array}{l}6 \\
2\end{array}$ & $\begin{array}{l}1 \\
0\end{array}$ & $\begin{array}{l}0 \\
0\end{array}$ \\
\hline $\begin{array}{l}\text { Other African } \\
\text { countries } †\end{array}$ & $\begin{array}{l}\text { PPNG } \\
\text { Non-PPNG }\end{array}$ & $\begin{array}{l}15 \\
38\end{array}$ & $\begin{array}{l}10 \\
25\end{array}$ & $\begin{array}{r}4 \\
10\end{array}$ & $\begin{array}{l}1 \\
1\end{array}$ & $\begin{array}{l}0 \\
1\end{array}$ & $\begin{array}{l}0 \\
1\end{array}$ \\
\hline
\end{tabular}

Pro = proline; $\mathrm{Arg}=$ arginine; $\mathrm{PPNG}=$ penicillinase-producing $\mathbf{N}$ gonorrhoeae

*West African countries include Ghana, Ivory Coast, and Nigeria

tCameroon, Central African Republic, Ethiopia, Kenya, South Africa, Zambia, and Zaire 
with our own findings that PPNG from African sources belong to serogroup WI while the auxotype could vary between the wild type, proline-requiring, and arginine-requiring types. Since the four PPNG strains harbouring $4.4 \mathrm{mdal}$ plasmid from West Africa all belonged to serogroup WI and shared the same antigenic specificities within the serogroup, we conclude that these strains are indigenous to West Africa, while the three PPNG strains with 4.4 mdal plasmid from other African countries in serogroup WII were imported into those countries.

It is interesting to note that six out of seven PPNG strains carrying 4.4 mdal plasmid were proline requiring and the one remaining strain was wild type. This finding is in accord with previous reports ${ }^{36}$ that $4.4 \mathrm{mdal}$ plasmid is found predominantly in prolinerequiring gonococcal isolates. The problem of stability of the $4.4 \mathrm{mdal}$ plasmid in West African PPNG strains requiring proline and belonging to serogroup WI might be the factor determining the low prevalence of 4.4 mdal plasmid in PPNG isolates from West Africa.

We conclude that serogrouping and auxotyping of $N$ gonorrhoeae are valuable adjuncts to the epidemiological studies of PPNG infections. Furthermore, our data show that all the different plasmid patterns except the combination of $24.5 \mathrm{mdal}$ and 3.2 mdal plasmids reported from all other geographical areas are present in Africa.

T O Odugbemi is a recipient of the Fogarty International Fellowship of the National Institutes of Health (fellowship No 1 Fo5 TWO 3107-01). We thank Joan S Knapp for providing the reagent for serogrouping. We are indebted to many microbiologists throughout Africa who submitted gonococcal isolates to our laboratory.
References

1. Jephcott AE, Dickgiesser N, McClean AM. Penicillinase-producing gonococci in Britain. Lancet $1981 ;$ ii:247-8.

2. Dillon JR, Pauze M. Appearance in Canada of Neisserio gonorrhoeae strains with a 3.2 megadalton penicillinaseproducing plasmid and a $24 \cdot 5$ megadalton transfer plasmid. Lancet 1981 ;ii:700.

3. Ansink-Schipper MD, Woudstra R. Further spread of plasmids among different auxotypes of penicillinase-producing gonococci. Lancet 1982;i:445.

4. Johnston NA, Kolator B. Emergence in Britain of betalactamase-producing gonocci with new plasmid combination. Lancet 1982; i:445-6.

5. Anderson B, Odugbemi T, Johnson S. Penicillinase-producing Neisseria gonorrhoeae strains from Nigeria with Far-Easterntype plasmid. Lancet 1982;i:676.

6. Perine PL, Thornsberry C, Schalla $\mathrm{W}$ et al. Evidence for two distinct types of penicillinase-producing Neisseria gonorrhoeae. Lancet 1977;ii:993-5.

7. Roberts M, Falkow S. Conjugal transfer of $\mathbf{R}$ plasmids in Neisseria gonorrhoeae. Nature 1977;266:630-1.

8. Knapp JS, Holmes KK. Disseminated gonococcal infections caused by Neisseria gonorrhoeae with unique nutritional requirements. J Infect Dis 1975;132:204-8.

9. LaScolea LJ jun, Young FE. Development of a defined minimal medium for the growth of Neisseria gonorrhoeae. Appl Microbiol 1974;28:70-6.

10. Bygdeman S, Kallings I, Danielsson D. Serogrouping and auxotyping for epidemiological study of beta-lactamaseproducing Neisseria gonorrhoeae strains isolated in Sweden. Acta Derm Venereol (Stockh) 1981;61:329-34.

11. Sandstrom E, Danielsson D. Serology of Neisseria gonorrhoeae: classification by coagglutination. Acta Pathol Microbiol Scand (B) 1980;88:27-38.

12. Sandstrơm EG, Knapp JS, Buchanan TB. Serology of Neisseria gonorrhoeae: W-antigen serogrouping by coagglutination and protein I serology by enzyme-linked immunosorbent assay both detect protein I antigens. Infect Immun 1982;35:229-39.

13. Handsfield HH, Sandström EG, Knapp JS et al. Epidemiology of penicillinase-producing Neisseria gonorrhoeae infections: analysis by auxotyping and serogrouping. $N$ Engl $J$ Med 1982;306:950-4.

14. O'Callaghan CH, Morris A, Kirby SM, Shingler AH. Novel method for detection of beta-lactamase by using cephalosporin substrate. Antimicrob Agents Chemother 1972;1:283-8.

15. Odugbemi TO, Hafiz S, McEntegart MG. Penicillinaseproducing Neisseria gonorrhoeae: detection by starch paper technique. Br Med J 1977;ii:500.

16. Meyers JA, Sanchez D, Elwell LP, Falkow S. Simple agarose gel electrophoretic method for identification and characterization of plasmid deoxyribonucleic acid. J Bacteriol 1976;127:1529-37. 